\title{
Ironia e humor como double bind
}

\author{
DÉBORA RACy SOARES \\ Universidade do Estado de Mato Grosso
}

ronia e bumor na literatura é o primeiro de uma série de três livros de Lélia Parreira Duarte a serem publicados. Nele, questões gerais ligadas à ironia e ao humor são tratadas através de textos importantes da literatura brasileira e internacional. Desfilam pelo livro autores como António Vieira, Camilo Castelo Branco, Dostoiévski, Eça de Queirós, Fernando Pessoa, Fernão Mendes Pinto, Guimarães Rosa, Helvécio Ratton, Luís de Camões, Machado de Assis e Mário de Sá-Carneiro. Adiantamos que o segundo volume da série será dedicado a autores portugueses contemporâneos, como Lobo Antunes, Carlos de Oliveira, Augustina Bessa-Luís, entre outros. No terceiro volume, Lélia promete deter o olhar à obra de Augusto Abelaira, escritor português falecido em 2004 que dizia estar a escrever sempre o mesmo romance.

Ao folhearmos Ironia e bumor na literatura, chamam atenção as últimas páginas que a autora, com modéstia, intitula "Esboço de uma bibliografia sobre ironia e humor". Seria "esboço", não fossem as mais de quatrocentas referências bibliográficas listadas sobre o assunto! Só por isso, o livro já seria indispensável para os que se dedicam ao estudo da ironia e do humor. Entretanto, o melhor ainda está por vir. O prazer da leitura nos acompanha ao longo dos vinte ensaios, escritos entre 1983 e 2006, e agrupados em blocos, de acordo com os temas tratados. O primeiro ensaio é inédito, enquanto os demais estavam dispersos em revistas de literatura e anais de congressos.

O ensaio de abertura, "Arte \& manhas da ironia e do humor", encara a ironia como uma espécie de double bind, embora a autora não faça alusão ao termo. Em suas palavras, o paradoxo da ironia "apresenta-se simultaneamente como necessidade e como impossibilidade de relato completo da realidade" (DUARTE, 2006: 17). É bom esclarecer que Lélia refere-se à ironia românti- 
ca, que, na verdade, não diferencia da ironia moderna, como veremos no decorrer do livro. Em sua opinião, a ironia romântica é uma estratégia ou "arte \& manha" encontrada para enfrentar o paradoxo do double bind, necessário e impossível. Por meio dela, introduz-se na obra a figura de um eu "representante da representação", como diz Lacan, capaz de revelar os artifícios de uma literatura que se assume antimimética par excellence, pois desnuda seu próprio fingimento (DUARTE, 2006: 17). A ironia romântica, como explica, não é da "época romântica, mas elemento constitutivo do romantismo alemão, do romantismo francês e de movimentos semelhantes" (DUARTE, 2006: 42).

Nesse ensaio inicial, Lélia parte de Muecke para relembrar a dificuldade de se chegar a um consenso sobre a definição do conceito de ironia. Some-se a esse agravante o fato de "cada autor te(r) a sua própria ironia" (DUARTE, 2006: 18). Além do mais, a ironia tem sido estudada sob perspectivas diferentes, o que contribuiu para uma profusão de tipos variados, que passam pela ironia trágica, cômica, dramática, filosófica, socrática, retórica, verbal, entre outras. No entanto, Lélia se atém a dois tipos especiais de ironia: a ironia retórica e a ironia romântica.

Segundo as manhas da arte retórica, esse tipo de ironia apontaria para o contrário do que é dito, revelando uma mentira em potencial implícita na linguagem. Para Lausberg, retomado por Lélia, a ironia retórica pode facilmente ser utilizada com finalidades ideológicas, pois trabalha no terreno do binarismo. Em outro momento do livro, Lélia demonstra como esse tipo de ironia é recorrente nos discursos de António Vieira, que a aproveita em prol de determinados interesses, visando à manutenção do poder português.

Já a chamada ironia romântica, desenvolvida em torno das idéias dos primeiros românticos de Iena, cuja figura central é Schlegel, teve o mérito de problematizar a idéia de representação em arte. A estética schlegeliana, indo na contramão de Hegel, cujo idealismo foi marcado por princípios da fenomenologia, assegura uma realidade que é própria à arte, ou seja, eleva à segunda potência seu caráter ficcional, além de incluir a reflexão sobre o próprio fazer artístico no cerne do processo de composição. A ironia romântica, portanto, não nos deixa esquecer que arte é mediação, para utilizar uma palavra cara a Adorno, isto é, põe o dedo na (má) consciência e não admite qualquer naïveté ou desatenção do leitor. Salvas as divergências em torno do conceito de ironia, uma coisa é certa: "não há ironia sem ironista” (DUARTE, 2006: 19). E 
acrescentaríamos, nas trilhas da ironia romântica: não há ironista sem leitor da ironia. Portanto, se o ironista é alguém que percebe e explora as ambigüidades da linguagem em suas múltiplas possibilidades de sentido, o leitor da ironia precisa ser capaz de perceber as intenções do autor. Em outras palavras: para rir da piada ou encontrar graça no texto, exige-se que o leitor estabeleça certo pacto de cumplicidade com o autor. Com uma ressalva: a cumplicidade é tão fingida quanto o próprio texto. Se o leitor precisa entrar na história do autor para entender a ironia, ao mesmo tempo, é necessário que ele saiba guardar distância e não se deixar engabelar pelo autor. Isto é, ele não pode cair no conto do vigário, mas precisa entender como ele se articula.

Nesse sentido, o leitor também caminha na corda bamba do double bind e deve ser tão astuto quanto o escritor, tão hipócrita quanto Baudelaire, tão cheio de dores fingidas quanto Fernando Pessoa... Ele também deve retribuir a piscadela do autor, pois não deixa de ser, como um certo personagem de nossa história literária, filho de uma "pis(c)adela e de um beliscão". Em se tratando de ironia romântica, não parece haver muito espaço para leitores ingênuos, que acreditam piamente nas verdades dos textos. $\mathrm{O}$ rebolado irônico faz, de fato, o (bom) leitor questionar as suas próprias verdades ou aquelas estabelecidas. Talvez seja por isso que a ironia romântica seja um recurso lingüístico tão sedutor, sempre a nos lembrar que as "palavras não têm um sentido fixo e único, mas podem variar conforme o contexto" (DUARTE, 2006: 22). A arte como jogo especular confirma a idéia de reflexão infinita valorizada pelos primeiros românticos alemães. Refletir a reflexão não deixa de ser uma maneira de assumir a ironia e o humor como double bind.

\section{Referência Bibliográfica}

DUARTE, Lélia Parreira. Ironia e humor na literatura. Belo Horizonte/São Paulo, Ed. PUC Minas/Alameda, 2006. 